\title{
Erosion Exploration of Transfer of Control Rights of the Large Shareholder to the Benefits of Small and Medium Shareholders
}

\author{
Xiaojun Deng \\ School of Economics and Management \\ Xi'an Shiyou University \\ Xi'an, Shaanxi Province, 710065 \\ dxj0624@126.com
}

\author{
Xiaofeng Liu \\ School of Economics and Management \\ Xi'an Shiyou University \\ Xi'an, Shaanxi Province, 710065
}

\begin{abstract}
Transfer efficiency of control rights is a criterion for judging the advantages and disadvantages of the control transfer system and its governance performance. After the completion of the split share reform, a new round of transfer of control rights of the large shareholder appeared in the capital market of China after the completion of the full circulation era. Its financial consequences have also reduced the efficiency of the transfer of control right as well as the direct erosion of the financial interests of the small and medium shareholders. Based on the analysis of the existing research literature system at home and abroad, this paper applies the large-scale equity transaction premium method to the empirical evidence of the transfer of control rights of the large shareholder of China's A-share market from 2012 to 2016: The majority of the original large shareholder can gain positive private gains of control rights during the transfer of control rights, but there is a big gap in the ability of different listed companies to obtain private gains of control rights, showing that the transfer of control rights of the large shareholder will erode the interests of small and medium shareholders. Meantime, when state-owned listed companies transfer control rights of the largest shareholder, the private gains from obtaining control rights are smaller than those of nonstate-owned listed companies and non-state-owned listed companies have implemented more erosion of interests in small and medium shareholders during the transfer of control rights. This research conclusion provides a brand-new governance perspective for the improvement of the investor protection system in China's capital market, especially the protection of small and medium investors.
\end{abstract}

Keywords-largest shareholder; transfer of control rights; financial erosion; large equity transaction premium method

\section{INTRODUCTION}

The equity of listed companies in China's capital market is generally concentrated. After all circulation, the transfer of control rights of the large shareholder of listed companies is still frequent. The largest shareholder has significant research value in the process of transferring control rights, which has infringement on the interests of other shareholders and the quantitative characteristics and influencing factors of the infringement of interests. For example, it can help reduce the company's agency costs, ensure the company's operation and development quality, and improve the company's value. And it

The Research Achievements of "The Stealth Financial Capital Research of Corporate Finance" (Project number: 0109-290088283) Supported by Xi'an Shiyou University High-level Talent Support Project. can help improve the investor protection system in the capital market, enhance investor confidence, improve corporate financing capabilities, and maintain the stability of the capital market. Besides, it can contribute to the sustainable development of the financial market. Perfect investor protection system is the basis for the sustainable development of the financial market. The better the investor protection is, the stronger the anti-risk ability of the financial market and the stronger the development capability are. In addition, it will help promote the growth of the real economy, properly identify, measure and prevent violations by the large shareholder, improve the corporate governance system, and improve the investor protection system, effectively improve the efficiency of resource allocation in the capital market and promote the role of the capital market in supporting the growth of the real economy.

Therefore, this paper proposes to discuss the erosion exploration of transfer of control rights of the large shareholder to the benefits of small and medium shareholders.

\section{ECONOMETRIC Model of EROSION of SMALl AND Medium SHAREHOLDERS' INTERESTS}

Since the concept of private ownership of control rights[1] was formally put forward, some literature started to study the measurement of private benefits of control rights. At present, the more common way is to use indirect method to measure private benefits of control rights. Common methods include large equity trading premium method, differential voting premium method and others [2].

\section{A. Large Equity Transaction Premium Method}

This method is the most widely used method for estimating the control premium [3], which was originally proposed by Barclay and Holderness (1989) [4]. Scholars like Mikkelson and Regassa (1991), Dyck and Zingales (2004), and Altanasov (2005)[5] also used this method to measure the control premium. The basic principle of the law is that when the transfer of control rights is performed, the transfer price of a large transaction controlled by a large shareholder is compared with a benchmark price, and the difference is considered to be the abnormal return obtained by a major shareholder using 
control rights. Most of the researchers compared the price of the company's stock trading price in the case of a large transaction transfer announcement to the capital market in the next trading day. The econometric model of this method is as follows:

$$
P B C=\frac{P_{b}-P_{k}}{P_{k}}
$$

Among them, PBC indicates the level of private benefits of control rights, $\mathrm{A}$ is the transfer price for the major transaction controlled by the major shareholder, and B is the transaction price for the transfer of the company's stock on the capital market on the next trading day.

Among them, PBC indicates the level of private benefits of control rights, $P_{\mathrm{b}}$ is the transfer price for the major transaction controlled by the major shareholder, and $P_{e}$ is the transaction price for the transfer of the company's stock on the capital market on the next trading day.

Atanasov (2005) ${ }^{[6]}$ considers that there are two defects in the method. The first one is benchmark price determination. Because the difference between the transfers price of a block transaction controlled by a shareholder and a benchmark price is the measure of the controlling shareholder's earnings. Under the condition that the major shareholders control the price of the bulk transaction, the choice of the benchmark price will directly affect the result of the infringement of the interests of the large shareholders. Second, under this calculation method, the expropriation of interest of large shareholders is regarded as a function of the established equity structure, and the ownership structure is treated as an exogenous variable that has nothing to do with company characteristics, which is contrary to most of the literature views (eg, Demsetz and Lehn, 1985).

\section{B. Differential Voting Rights Premium Method}

This method was proposed by Lease, McConnell, and Mikkelson (1984) when analyzing the existence of two types of publicly traded common stocks in the United States (where the same cash flow rights and voting rights have different premiums). The basic principle of the method: For companies that have the same cash flow rights but different voting rights, the difference between the voting rights and the non-voting rights is a measure of the private gains of control rights.
Nenova (2003) [7] proposed the differential voting rights premium model as follows:

$$
V P=\frac{P_{m}(t)-P_{l}(t)}{1-K} \times \frac{N_{m}-N_{l} K}{2\left(N_{m} P_{m}(t)+N_{l} P_{l}(t)\right)}
$$

Among them, $P_{m}(t)$ and $P_{l}(t)$ are the average price of a voting stock and a non-voting stock for one week, $N_{m}$ and $N_{l}$ are the number of shares corresponding to two types of stocks, and $\mathrm{K}$ is the ratio of the voting rights of non-voting stocks and voting stocks.

III. EMPIRICAL OF EROSION OF TRANSFER OF CONTROL RightS OF THE LARGE SHAREHOLDER TO THE BENEFITS OF SMALL AND MEDIUM SHAREHOLDERS

This article takes a sample of 152 listed companies that have transferred the control rights of the largest shareholder of the listed company as the sample, and eliminates the data based on the following principles: 1 . The transfer of control rights of the largest shareholder is voluntary and equity transactions are conducted in accordance with market transaction principles; 2 . The equity transfer involved in the sample has been completed, the transaction has been approved by the relevant department, and the equity transfer has been completed; 3. Missing data from listed companies, ST-listed companies, etc. were deleted. After the selection, 132 listed companies were selected as sample companies.

This paper uses the large equity transaction premium method to calculate the private gains of control rights, and selects the "the arithmetic mean of stock prices in the stock exchange market for the first trading day and the 28 trading days before the announcement date (30 trading days in total)" as the "basket price of comparatively large equity transaction" in the measurement model when the transfer of control rights of the largest shareholder and equity transfer transaction information is announced. After calculation, it is shown in TABLE I that private ownership of the transfer of control rights of the largest shareholder of the sample company after full circulation.

\begin{tabular}{|c|c|c|c|c|c|}
\hline Project & Number of sample $(\mathrm{N})$ & $\begin{array}{l}\text { Minimum } \\
\text { (Min) }\end{array}$ & $\begin{array}{l}\text { Maximum } \\
\text { (Max) }\end{array}$ & Mean & Standard deviation (Sta.De) \\
\hline Shareholding ratio of the largest shareholder & 132 & 7.93 & 67.5 & 27.14 & 13.12 \\
\hline The logarithm of the company's assets & 132 & 14.13 & 25.33 & 21.14 & 1.25 \\
\hline Asset-liability ratio & 132 & 0.03 & 0.95 & 0.39 & 0.23 \\
\hline Return on equity & 132 & -0.77 & 0.66 & 0.04 & 0.16 \\
\hline Turnover of total capital & 132 & 0.001 & 2.438 & 0.58 & 0.41 \\
\hline Private benefits of control (PBC) & 132 & -0.55 & 2.37 & 0.19 & 0.472 \\
\hline Equity balance & 132 & 0.05 & 2.48 & 0.83 & 0.624 \\
\hline
\end{tabular}

TABLE I. LARGEST SHAREHOLDER CONTROL RIGHTS TRANSFER PREMIUM T ABLE AFTER FULL CIRCULATION

From the perspective of the proportion of shares involved in the equity transaction transfer from the sample company's largest shareholder control rights, the share that the largest shareholder transfers accounts for the lowest total share of the company is $7.93 \%$ (only two companies with less than $10 \%$ of total shares transferred to the company), and the highest is $67.5 \%$. Under 
normal circumstances, more than $5 \%$ of the transfer of shares is considered to have the potential to cause a transfer of control rights and the average share of the largest shareholder transfer share in the study sample amounts to $27.14 \%$. Meantime, the largest shareholder of the selected sample has changed its position as the largest shareholder after transferring shares. Therefore, regardless of the perspective, the transfer of ownership of the large shareholder of the selected sample listed company and the change of the large shareholder have led to the transfer of control rights of the listed company.

From the sample company's capital structure, the average asset-liability ratio of the listed company with a large shareholder change is 0.39 ; in the sight of operating capability indicators, the minimum value of the sample company's turnover of total capital is 0.001 , the highest is 2.45 and the average value is 0.41 ; from the point of profitability indicators, the lowest return on equity for the sample companies is -0.77 , the highest is 0.66 and the average is 0.04 , indicating that the controlling share transfer of large shareholder has a high assetliability ratio and poor profitability. The private equity gains of control rights of the 132 listed companies after transfer of largest holder shareholder control rights are calculated as: there are 85 companies with positive private benefits of control rights, accounting for $64.39 \%$, and 47 private companies whose private benefits of control rights are negative, accounting for $35.61 \%$, showing that most companies that have transferred control rights during 2012-2016 have obtained positive control rights private benefits and the largest shareholder violated the interests of other shareholders when most sample companies transfer control rights in the largest shareholder. The lowest private benefit of control rights is -0.55 , the highest value is 2.48 , and the average value is 0.83 . This shows that in the process of control rights transfer, the price of the bulk equity transfer is higher than the $0.83 \%$ of the arithmetic mean of 'the stock price on the stock exchange market for a trading day after the 1st announcement date and 28 trading days before the announcement date (30 trading days in total)", the maximum premium level is $248 \%$, and the minimum premium is $-0.55 \%$, indicating that the overall level of private ownership of controlling shareholder's master shareholder in the transfer process of master shareholder is positive, but the level of private ownership of control gains for different samples is quite different.

The minimum value of the selected sample company's shareholding balance is 0.05 , the maximum is 2.48 and the average degree of balance between the second and fifth shareholders for the largest shareholder is 0.83 , showing that the sample companies with largest shareholder control rights transfer after full circulation have high equity concentration, and the second to fifth largest shareholders have difficulty in forming effective checks and balances on the largest shareholder.

In summary, after the full circulation, largest shareholder that have changed or transferred control rights has a higher asset-liability ratio for listed companies, poor asset operating ability and profitability, high ownership concentration and low equity balance. It is difficult for the second to fifth largest shareholders to form an effective check against the large shareholder. After calculation, it is verified that most of the original largest shareholders can obtain positive private gains of control rights during the transfer of control rights, but there is a big gap in the ability of different listed companies to obtain private benefits of control rights. This shows that the transfer of control rights of largest shareholders will infringe on the interests of other shareholders and affect the economic interests of other shareholders, which is consistent with the conclusions drawn from most previous research literature.

In order to further analyze the status of control rights premiums for the largest shareholders control rights transfer transactions of listed companies of different nature, this paper classifies the overall sample of 132 listed companies by the nature, taking listed companies of state-owned enterprises as an inspection team, and non-state listed companies such as private-owned enterprises and foreign-funded enterprises as an inspection team. The descriptiveness and analysis of the control rights premium status of its largest shareholder control rights transfer transaction are as follows:

TABLE II. CONTROL RIGHT S TRANSFER PREMIUM T ABLE OF ST ATEOWNED AND NON-ST ATE-OWNED LISTED COMPANIES' LARGEST SHAREHOLDERS

\begin{tabular}{|l|c|c|c|c|c|}
\hline $\begin{array}{l}\text { Company } \\
\text { nature }\end{array}$ & $\begin{array}{l}\text { Sample } \\
\text { Number } \\
(\mathrm{N})\end{array}$ & $\begin{array}{c}\text { Minimum } \\
\text { (Min) }\end{array}$ & $\begin{array}{c}\text { Maximum } \\
\text { (Max) }\end{array}$ & Mean & $\begin{array}{l}\text { Standard } \\
\text { deviation } \\
\text { (Sta.De) }\end{array}$ \\
\hline $\begin{array}{l}\text { State-owned } \\
\text { listed } \\
\text { companies }\end{array}$ & 20 & -0.45 & 0.745 & 0.068 & 0.294 \\
\hline $\begin{array}{l}\text { Non-state } \\
\text { listed } \\
\text { companies }\end{array}$ & 112 & -0.55 & 2.37 & 0.217 & 0.492 \\
\hline
\end{tabular}

According to the classification of the nature of listed companies, there are 20 samples of transfer of control rights of state-owned listed companies, of which 12 companies have positive private gains of control rights, accounting for $60 \%$, and 8 companies have negative private gains of control rights, accounting for 40\%. A total of 112 non-state-owned listed companies have transferred their control rights, of which 71 companies have positive private ownership of control rights, accounting for $63.39 \%$ and 41 companies have negative private ownership of control rights, accounting for $36.61 \%$. The mean value of the control rights transaction transfer premium for state-owned listed companies is 0.068 , and the average value of the transfer of control rights for state-owned listed companies is 0.217 . The above data shows that when state-owned listed companies transfer control rights of a large shareholder, the private gains from obtaining control rights are smaller than non-state-owned listed companies and non-state-owned listed companies have more infringements of small and medium shareholders in the transfer of control rights.

\section{CONCLUSION}

1. After full circulation, the listed company with a large shareholder has a higher asset-liability ratio, a lower asset operating capacity and profitability, a higher degree of equity concentration, and a lower degree of equity checks and balances and it is difficult for the second to fifth largest shareholders to form an effective check against the largest shareholder. 
2. In the process of control rights transfer, the original largest shareholder can obtain positive private benefits of control, but there is a big gap in the ability of different listed companies to obtain private benefits of control rights, indicating that the transfer of control rights of the large shareholder will erode the interests of minority shareholders.

3. When state-owned listed companies transfer control of largest shareholder control, the private gains from obtaining control rights are smaller than non-state-owned listed companies. Non-state-owned listed companies have more erosion of interests in small and medium shareholders during the transfer of control rights.

\section{REFERENCES}

[1] Grossman \& Hart. One Share-one Vole and the Market for Corporate Control[J].Journal of Financial Economics,1988(20):175 - 202.

[2] Shieifer, A., R. Vishny. A survey of Corporate Governance [J].Journal of political Economy, 1997, 52(2):737-783

[3] Tang Zongming \& Jiang Wei. Empirical Analysis on the Infringement of the Large Shareholders in Chinese Listed Companies [J].Economic Research Journal, 2002(9):44-50.(In Chinese)

[4] Han Dezong \& Ye Chunhua. Theoretical and Empirical Research on Control Benefits [J]. Statistical Research, 2004(02): 42-46. (In Chinese)

[5] Xi Junfang \& Yu Peiyou. Research on the Transfer of Control Rights of Listed Companies in China: An Analysis Based on Business Performance [J]. Nankai Business Review, 2006(04):42-48. (In Chinese)

[6] Xiao Shaoping. Information Disclosure, Investor Information Identification and Game Equilibrium of Listed Company [J]. Journal of Central University of Finance \& Economics, 2012(02):90-96. (In Chinese)

[7] Jiang Donghan. Review and Improvement of the Measurement Model of Private Benefits of Control [J]. Journal of Chongqing University (Social Sciences Edition), 2012, 18(05):70-76. (In Chinese) 